Original

\title{
Odontogenic tumors in an Iranian population: a 30-year evaluation
}

\author{
Nasrollah Saghravanian ${ }^{1)}$, Hamid Jafarzadeh ${ }^{2)}$, Nazanin Bashardoost ${ }^{1)}$, \\ Nooshin Pahlavan ${ }^{3)}$ and Iman Shirinbak ${ }^{4)}$ \\ ${ }^{1)}$ Department of Oral and Maxillofacial Pathology, Faculty of Dentistry and Dental Research Center, \\ Mashhad University of Medical Sciences, Mashhad, Iran \\ ${ }^{2)}$ Department of Endodontics, Faculty of Dentistry and Dental Research Center, \\ Mashhad University of Medical Sciences, Mashhad, Iran \\ ${ }^{3)}$ General Dentist, Mashhad, Iran \\ ${ }^{4)}$ Department of Oral and Maxillofacial Surgery, Tehran University of Medical Sciences, Tehran, Iran
}

(Received 24 November 2009 and accepted 21 May 2010)

\begin{abstract}
Oral and maxillofacial pathology has paramount importance in connecting basic science and clinical features; progress in this field will improve diagnosis and treatment. Although the prevalence of odontogenic tumors varies in different geographic sites, there are no reports in English on the relative frequency of odontogenic tumors in Iran. In the present 30-year retrospective study, the case records of all patients referred to the Mashhad Faculty of Dentistry during the period 1978-2008 were evaluated. Subsequently, all lesions diagnosed as odontogenic tumors were subjected to microscopic reevaluation. Data regarding sex, gender, location, and histopathology were gathered. Among 8,766 patients, only 165 odontogenic tumors $(1.9 \%)$ were found, with a mean age of 26.3 years (range 6-81 years). One hundred and fifty-eight tumors were central with high frequency in the posterior region of both jaws especially in the mandible and seven were peripheral tumors, including five in the posterior mandible and two in anterior maxilla. Malignant transformation was seen in three cases as malignant ameloblastoma (1.8\%). The most common tumor was ameloblastoma, followed by odontoma, odontogenic myxoma, and adenomatoid
\end{abstract}

Correspondence to Dr. Hamid Jafarzadeh, Department of Endodontics, Faculty of Dentistry and Dental Research Center, Mashhad University of Medical Sciences, Vakilabad Blvd, Mashhad, Iran

Tel: +98-511-8829501

Fax: +98-511-7626058

E-mail: JafarzadehBH@mums.ac.ir \& hamid_j365@yahoo.com odontogenic tumor. Nevertheless, odontogenic tumors occurred more in females in the third decade with affinity for the posterior mandible in this study. ( $J$ Oral Sci 52, 391-396, 2010)

Keywords: odontogenic tumor; retrospective study; prevalence.

\section{Introduction}

Odontogenic tumors are those lesions which originate from odontogenic epithelium. They remain entrapped, either within the jaws or in adjacent soft tissues (1). They can be classified by location (peripheral or central) and biologic behavior as benign or malignant. However, the most accepted World Health Organization (WHO) classification has divided them into three subclasses: epithelial, mesenchymal, and mixed $(2,3)$.

From a biological point perspective, some of these lesions represent hamartomas with various degrees of differentiation, while the rest are benign or malignant neoplasms with variable behavior (2). Therefore, it is very important to form a set of criteria such as age, gender, and location of lesion, in the management of these tumors. In the present study, odontogenic tumors were evaluated in an Iranian population over a 30-year period.

\section{Materials and Methods}

The case records from the Department of Oral and Maxillofacial Pathology of Mashhad Faculty of Dentistry, 
Mashhad, Iran served as the source of this 30-year retrospective study (1978-2008). All patients with lesions diagnosed as odontogenic tumor, were confirmed by microscopic reevaluation. Statistical analysis was performed using SPSS software (v. 13, SPSS Inc., Chicago, IL, US).

\section{Results}

Among 8,766 patients, only 165 cases were diagnosed as odontogenic tumors (1.9\%). Odontogenic tumors were more common in females and in the second or third decades of life with greater frequency in the posterior region of the mandible (Table 1). According to the WHO classification (2005), 88 cases of these diagnosed tumors were epithelial odontogenic tumors $(\mathrm{EOT}=53.4 \%), 54$ were mixed odontogenic tumors $(\mathrm{MixOT}=32.7 \%$ ), and 23 were mesenchymal odontogenic tumors (MOT $=13.9 \%$ ) (Table 2). These data revealed that $98.2 \%$ of the tumors were benign and only three (1.8\%) were malignant ameloblastoma, which were seen only in males.

Ameloblastoma consisting of all histological types (Fig. 1) was the most common odontogenic tumor (70 cases; $42.4 \%$ ); followed by odontoma (44 cases; $26.7 \%$ ); and odontogenic myxoma tumor and adenomatoid odontogenic tumor (15 cases each; 9.1\%) (Fig. 2). The rest were other tumors (21 cases; 12.7\%) (Table 3).

Centrally located tumors accounted for 158 cases
(95.7\%); whereas, only 7 cases $(4.3 \%)$ were peripheral. Among the peripheral odontogenic tumors, there were three cases of peripheral ameloblastoma (42.8\%), two cases of odontogenic myxoma, and one case each of odontoma and odontogenic fibroma.

\section{Discussion}

In the present study, ameloblastoma was the most common odontogenic tumor. The incidence of odontogenic tumors in the oromaxillofacial region was low and peripheral and malignant tumors were relatively rare.

Nevertheless, this study showed that odontogenic tumors occurred more frequently in females, especially in the third decade and in the posterior mandible than in the anterior area.

Histologically, EOT was most commonly found in the mandible and in men in their thirties. MixOT showed a similar pattern but females were affected more than males. Moreover, MOT occurred more in females and in the mandible but in the forth decade of life.

In the present study, the most common odontogenic tumor was ameloblastoma, followed by odontoma, odontogenic myxoma and adenomatoid odontogenic tumor each with 15 cases. Olgac et al. (15), in their 32-year study, showed the same results. Ogunsalu (7) noted that ameloblastoma was the most common odontogenic tumor

Table 1 Relative frequency of all odontogenic tumors

\begin{tabular}{|c|c|c|c|c|c|c|c|c|c|c|c|}
\hline \multicolumn{8}{|c|}{ Location } & \multirow{6}{*}{$\begin{array}{c}\text { Mean of } \\
\text { age }\end{array}$} & \multirow{2}{*}{\multicolumn{2}{|c|}{ Sex }} & \multirow{6}{*}{ Number } \\
\hline \multicolumn{4}{|c|}{ Peripheral } & \multicolumn{4}{|c|}{ Central } & & & & \\
\hline \multicolumn{4}{|c|}{7} & \multicolumn{4}{|c|}{158} & & & & \\
\hline \multicolumn{2}{|c|}{ Mandible } & \multicolumn{2}{|c|}{ Maxilla } & \multicolumn{2}{|c|}{ Mandible } & \multicolumn{2}{|c|}{ Maxilla } & & & & \\
\hline \multicolumn{2}{|c|}{5} & \multicolumn{2}{|c|}{2} & \multicolumn{2}{|c|}{112} & \multicolumn{2}{|c|}{46} & & $\mathrm{~F}$ & M & \\
\hline Pos. & Ant. & Pos. & Ant. & Pos. & Ant. & Pos. & Ant. & & & & \\
\hline 5 & 0 & 0 & 2 & 99 & 13 & 25 & 21 & 26.3 & 89 & 76 & 165 \\
\hline
\end{tabular}

Table 2 Frequency of odontogenic tumors based on histologic origin

\begin{tabular}{|c|c|c|c|c|c|c|c|c|}
\hline \multirow{4}{*}{ Type of tumor } & \multirow{4}{*}{ Number } & \multirow{2}{*}{\multicolumn{2}{|c|}{ Gender }} & \multirow{4}{*}{ Mean of age } & \multicolumn{4}{|c|}{ Location } \\
\hline & & & & & \multicolumn{2}{|c|}{ Central } & \multicolumn{2}{|c|}{ Peripheral } \\
\hline & & \multirow[t]{2}{*}{ Male } & \multirow[t]{2}{*}{ Female } & & \multicolumn{2}{|c|}{158} & \multicolumn{2}{|c|}{7} \\
\hline & & & & & Man & Max & Man & Max \\
\hline Epithelial & 88 & 48 & 40 & 24.4 & 71 & 14 & 3 & 0 \\
\hline Mesenchymal & 23 & 10 & 13 & 30.1 & 11 & 9 & 1 & 2 \\
\hline Mixed & 54 & 20 & 34 & 22.8 & 30 & 23 & 1 & 0 \\
\hline
\end{tabular}


(85.5\%), but found that odontoma was uncommon. Lu et al. (16) and Ochsenius et al. (17) also reported that ameloblastoma was the most common odontogenic tumor, and odontoma the forth most common. According to studies in Indian, Nigerian, and Tanzanian populations, ameloblastoma was the most common odontogenic tumor, followed by myxoma $(4,18,19)$. On the other hand, odontoma was the most common odontogenic tumor in studies performed in Europe and the United States, followed by ameloblastoma and odontogenic fibromyxoma $(13,20$ -

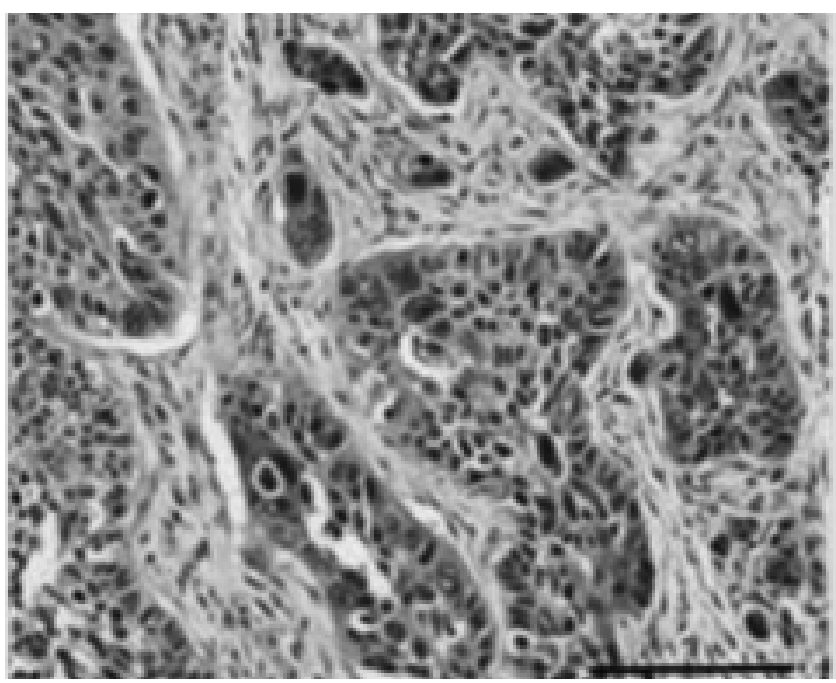

Fig. 1 Ameloblastic carcinoma.

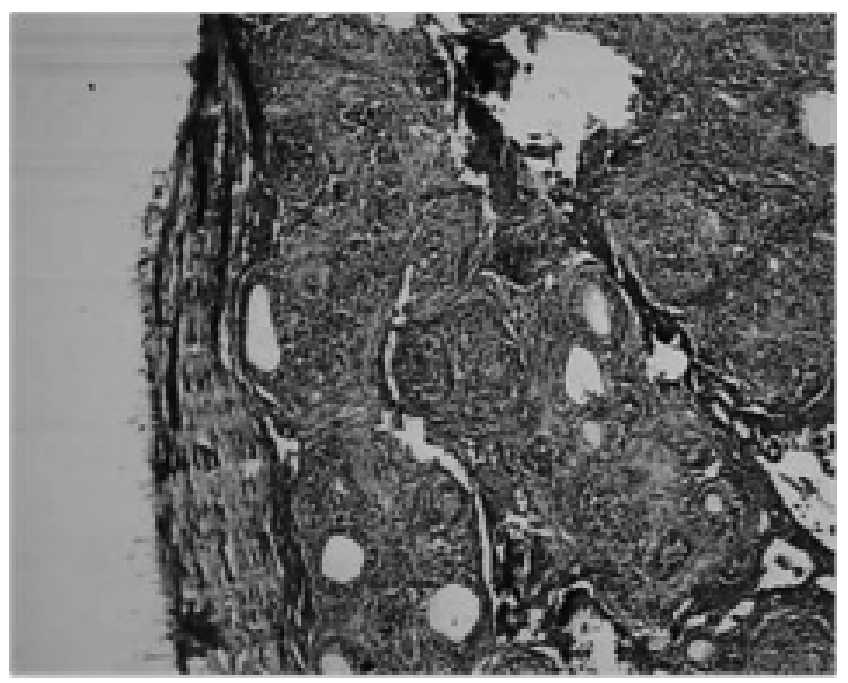

Fig. 2 Adenomatoid odontogenic tumor.

Table 3 Frequency of the most common odontogenic tumors

\begin{tabular}{|c|c|c|c|c|c|c|c|c|c|c|c|c|}
\hline \multirow{4}{*}{ Type of tumor } & \multirow{4}{*}{ number } & \multicolumn{2}{|c|}{ Gender } & \multirow{4}{*}{$\begin{array}{l}\text { Mean of } \\
\text { age }\end{array}$} & \multicolumn{8}{|c|}{ Location } \\
\hline & & \multirow{3}{*}{ male } & \multirow{3}{*}{ Female } & & \multicolumn{4}{|c|}{ central } & \multicolumn{4}{|c|}{ peripheral } \\
\hline & & & & & \multicolumn{2}{|c|}{ Man } & \multicolumn{2}{|c|}{ Max } & \multicolumn{2}{|c|}{ Man } & \multicolumn{2}{|c|}{ Max } \\
\hline & & & & & Ant. & Pos. & Ant. & Pos. & Ant. & Pos. & Ant. & Pos. \\
\hline Ameloblastoma & $\begin{array}{l}\text { Multicystic }=49 \\
\text { Unicystic }=15 \\
\text { Peripheral }=3 \\
\text { Malignant }=3\end{array}$ & 40 & 30 & 38.5 & 3 & 62 & 0 & 2 & 0 & 3 & 0 & 0 \\
\hline Odontoma & Complex $=27$ & 18 & 26 & 21.4 & 2 & 18 & 9 & 14 & 0 & 1 & 0 & 0 \\
\hline & Compound $=17$ & & & & & & & & & & & \\
\hline $\begin{array}{l}\text { Adenomatoid } \\
\text { odontogenic tumor }\end{array}$ & 15 & 3 & 12 & 19 & 3 & 1 & 9 & 2 & 0 & 0 & 0 & 0 \\
\hline Odontogenic myxoma & 15 & 7 & 8 & 25.1 & 3 & 4 & 1 & 5 & 0 & 0 & 2 & 0 \\
\hline $\begin{array}{l}\text { Ameloblastic } \\
\text { fibro-odontoma } \\
\text { (Fig. 3) }\end{array}$ & 5 & 1 & 4 & 23.4 & 0 & 5 & 0 & 0 & 0 & 0 & 0 & 0 \\
\hline $\begin{array}{l}\text { Ameloblastic fibroma } \\
\text { (Fig. 4) }\end{array}$ & 4 & 1 & 3 & unknown & 0 & 4 & 0 & 0 & 0 & 0 & 0 & 0 \\
\hline Odontogenic fibroma & 3 & 3 & 0 & 33.3 & 0 & 0 & 2 & 0 & 0 & 0 & 1 & 0 \\
\hline $\begin{array}{l}\text { Calcifying epithelial } \\
\text { odontogenic tumor } \\
\text { (Fig. 5) }\end{array}$ & 3 & 7 & 8 & 18.3 & 0 & 1 & 0 & 1 & 0 & 0 & 0 & 1 \\
\hline Odonto-ameloblastoma & 1 & 0 & 1 & unknown & 0 & 1 & 0 & 0 & 0 & 0 & 0 & 0 \\
\hline
\end{tabular}


Table 4 Comparison of the present study with large studies reported from different countries and regions

\begin{tabular}{|c|c|c|c|c|c|}
\hline Author & Country/region & Cases & $\begin{array}{l}\text { Top two of most } \\
\text { common OTs } \%\end{array}$ & $\begin{array}{c}\text { Male/female } \\
\text { ratio }\end{array}$ & $\begin{array}{l}\text { Maxilla/mandible } \\
\text { ratio }\end{array}$ \\
\hline Simon et al. (4) & Tanzania & 116 & $\begin{array}{l}\operatorname{AME}(78.45) \\
\operatorname{OM}(6.90)\end{array}$ & $1: 1.09$ & unknown \\
\hline Wu and Chan (5) & Hong Kong & 68 & $\begin{array}{l}\text { AME }(75.00) \\
\text { ODT }(7.35)\end{array}$ & $1: 1.06$ & $1: 2.40$ \\
\hline Simon et al. (6) & Tanzania & 211 & $\begin{array}{l}\text { AME (74.41) } \\
\text { OM (10.43) }\end{array}$ & $1: 1.05$ & $1: 5.82$ \\
\hline Ogunsalu (7) & Jamaica & 80 & $\begin{array}{l}\text { AME }(73.75) \\
\text { ODT }(12.50)\end{array}$ & unknown & $1: 7.75$ \\
\hline Present study & Iran & 165 & $\begin{array}{l}\text { AME (42.42) } \\
\text { ODT (26.66) }\end{array}$ & $1: 1.17$ & $1: 2.43$ \\
\hline Okada et al. (8) & Sri Lanka & 226 & $\begin{array}{l}\text { AME }(69.47) \\
\text { AOT }(9.29)\end{array}$ & $1: 1.11$ & $1: 3.91$ \\
\hline Ladeinde et al. (9) & Nigeria & 316 & $\begin{array}{l}\text { AME (63.01) } \\
\text { AOT (7.52) }\end{array}$ & $1.03: 1$ & $1: 4.08$ \\
\hline Luo and $\operatorname{Li~(10)~}$ & China & 802 & $\begin{array}{l}\text { AME }(59.60) \\
\text { ODT }(9.98)\end{array}$ & $1.14: 1$ & $1: 3.89$ \\
\hline Arotiba et al. (11) & Nigeria & 128 & $\begin{array}{l}\text { AME (59.38) } \\
\text { OM (16.41) }\end{array}$ & $1.10: 1$ & $1: 2.88$ \\
\hline Santos et al. (12) & Nigeria & 127 & $\begin{array}{l}\text { ODT }(50.40) \\
\text { AME }(30.70)\end{array}$ & $1: 1.76$ & $1: 1.36$ \\
\hline Fernandes et al. (13) & Brazil & 340 & $\begin{array}{l}\text { AME }(45.29) \\
\text { ODT }(25.00)\end{array}$ & $1: 1.23$ & $1: 1.94$ \\
\hline Avelar et al. (14) & Brazil & 238 & $\begin{array}{l}\text { AME }(23.70) \\
\text { OKC }(30.00)\end{array}$ & $1: 1.33$ & $1: 2.05$ \\
\hline
\end{tabular}

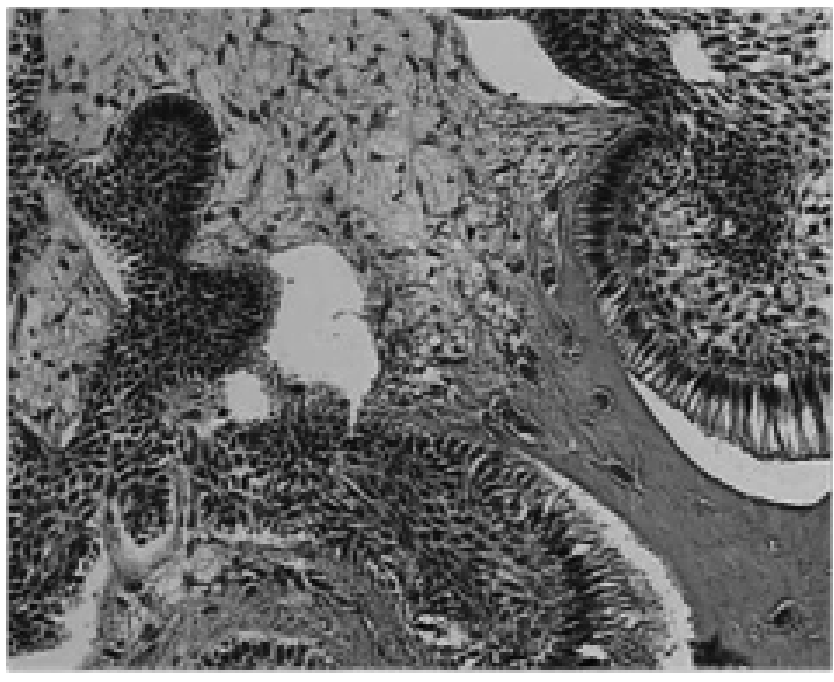

Fig. 3 Ameloblastic fibro-odontoma.

\section{4) (Table 4).}

In the present study, malignancy accounted for $1.8 \%$ of all the tumors, similar to other studies $(7,18,19,24)$. Lu et al. (6) and Jing et al. (25) reported 6\% malignancy in a Chinese population, whereas Fernandes (13) stated no malignancy among odontogenic tumors in a Brazilian population.

The majority of the cases in the present study were

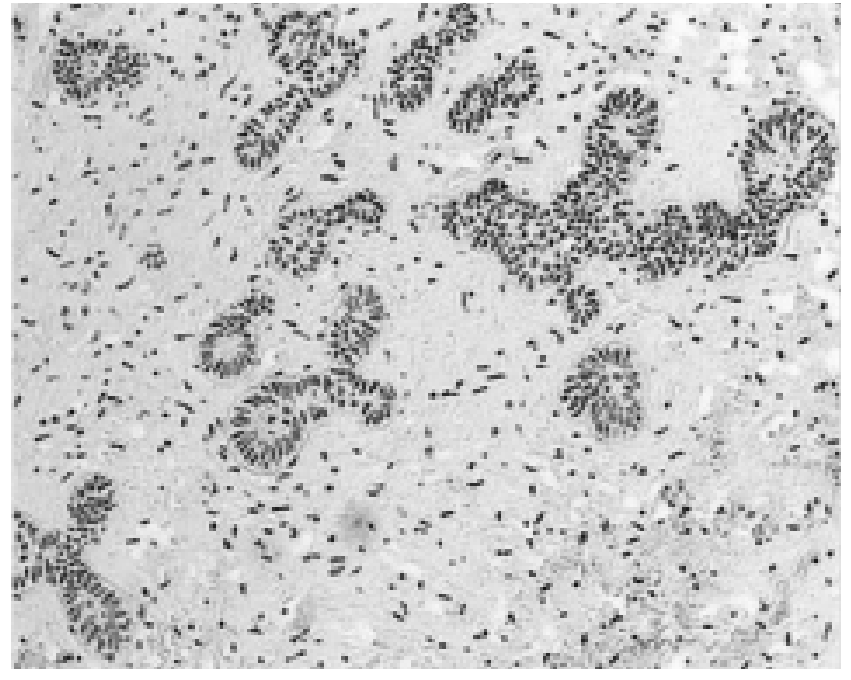

Fig. 4 Ameloblastic fibroma.

located centrally and only $4.3 \%$ peripherally, the most common one being peripheral ameloblastoma (42.8\%). Bucher et al. $(23,26)$ showed that $99.95 \%$ of total odontogenic tumors were central and only $0.05 \%$ were peripheral, and that the most common peripheral tumor was odontogenic fibromyxoma. The posterior region of the jaws was the most common location for odontogenic tumors in the present study (mandible $=63 \%$; maxilla $=$ 
Table 5 The most common clinical findings

\begin{tabular}{ll}
\hline Kind of tumor & Clinical findings \\
\hline Ameloblastoma & Swelling without pain (in most cases) \\
Lip paresthesis and pain (in 2 cases) \\
Adenomatoid odontogenic tumor & Swelling without pain \\
Calcifying epithelial odontogenic tumor & Swelling without pain/slow growth \\
Ameloblastic fibro-odontoma & Swelling without pain \\
Ameloblastic fibroma & Swelling without pain \\
Odonto-ameloblastoma & Delay in tooth eruption \\
Odontoma & Pain \\
& Swelling without pain (in large lesions) \\
Odontogenic fibroma & Delay in tooth eruption (in small lesions) \\
& Swelling without pain \\
Odontogenic myxoma & Tooth mobility \\
Cementoblastoma & Without pain \\
\hline
\end{tabular}

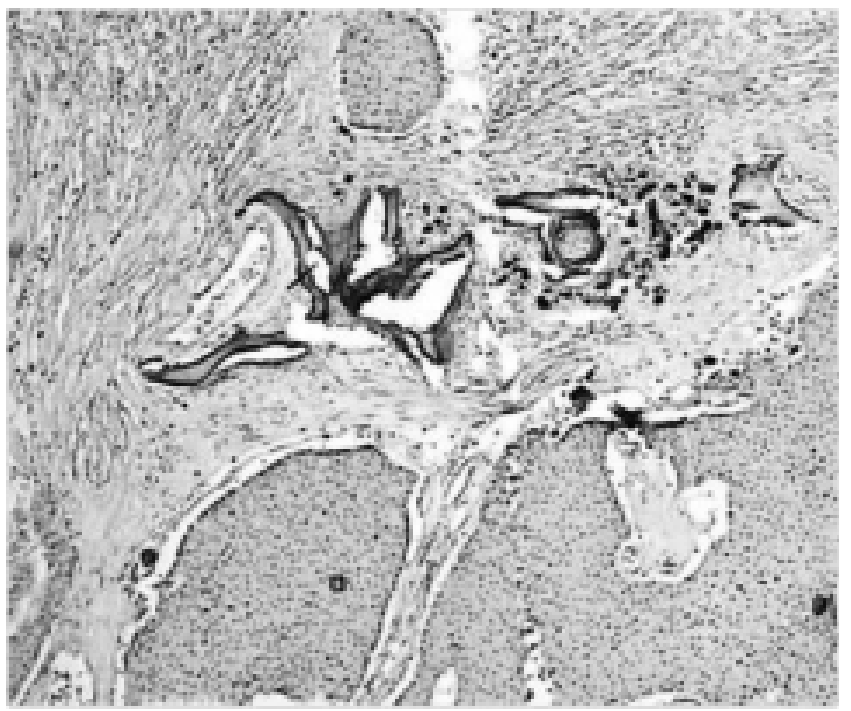

Fig. 5 Calcifying epithelial odontogenic tumor.

$15.2 \%)$ followed by anterior maxilla (13.9\%), which agreed with data from Olgac et al. (15). Although various studies showed greater occurrence of odontogenic tumor in the mandible than maxilla, Jing et al. (25) showed more odontogenic tumors in the maxilla.

In the present study, more cases appeared in the third decade, the ages ranging from 6 to 81 years with a mean of approximately 26 years. Jing et al. (25) observed a median age of about 32. Occurrence was predominantly in the second and third decade of life, as stated by Santos et al. (12) and Fernandes et al. (13), and was seen in a rather broad age group between second to fifth decades by Okada et al. (8) Furthermore, odontogenic tumors were seen more in females $(53.9 \%)$, than in males which is similar to other studies $(12,13,15)$. Jing et al. (25) showed a fourfold increase in odontogenic tumors in females over males.

The most common clinical findings in the present study are summarized in Table 5.

It should be added that according to the WHO classification in 2005, Odontogenic Keratocyst (OKC) has been renamed as Keratocystic Odontogenic Tumor (KCOT) and Calcifying Odontogenic Cyst (COC) has been renamed as Calcifying Cystic Odontogenic Tumor (CCOT). However, some of the standard references in the field of oral pathology $(1,2)$ still use the term OKC. According to this, OKC has not been considered as a tumor in this research.

Our findings revealed a low frequency of odontogenic tumors among oromaxillofacial lesions and a small percentage of malignancy. Odontogenic tumors are more common in the mandible and in females with most cases appearing in the second and third decades of life.

\section{References}

1. Regezi JA, Sciubba JJ, Jordan RCK (2008) Oral pathology: clinical pathologic correlation. 5th ed, Saunders, St Louis, 261-275. 
2. Neville BW, Damm DD, Allen CM, Bouqout J (2009) Oral and maxillofacial pathology. 3rd ed, Saunders, St Louis, 701.

3. Barnes L, Everson JW, Reichart P, Sidransky D (2005) World Health Organization classification of tumors. Pathology and genetics of head and neck tumors. IARC Press, Lyon, 281-286.

4. Simon EN, Merkx MA, Vuhahula E, Ngassapa D, Stoelinga PJ (2005) A 4-year prospective study on epidemiology and clinicopathological presentation of odontogenic tumors in Tanzania. Oral Surg Oral Med Oral Pathol Oral Radiol Endod 99, 598-602.

5. Wu PC, Chan KW (1985) A survey of tumours of the jawbones in Hong Kong Chinese: 1963-1982. Br J Oral Maxillofac Surg 23, 92-102.

6. Simon EN, Stoelinga PJ, Vuhahula E, Ngassapa D (2002) Odontogenic tumors and tumor-like lesions in Tanzania. East Afr Med J 79, 3-7.

7. Ogunsalu CO (2003) Odontogenic tumours from two centres in Jamaica. A 15-year review. West Indian Med J 52, 285-289.

8. Okada H, Yamamoto H, Tilakaratne WM (2007) Odontogenic tumors in Sri Lanka: analysis of 226 cases. J Oral Maxillofac Surg 65, 875-882.

9. Ladeinde AL, Ajayi OF, Ogunlewe MO, Adeyemo WL, Arotiba GT, Bamgbose BO, Akinwande JA (2005) Odontogenic tumors: a review of 319 cases in a Nigerian teaching hospital. Oral Surg Oral Med Oral Pathol Oral Radiol Endod 99, 191-195.

10. Luo HY, Li TJ (2009) Odontogenic tumors: a study of 1309 cases in a Chinese population. Oral Oncol 45, 706-711.

11. Arotiba JT, Ogunbiyi JO, Obiechina AE (1997) Odontogenic tumours: a 15-year review from Ibadan, Nigeria. Br J Oral Maxillofac Surg 35, 363-367.

12. Santos JN, Pinto LP, de Figueredo CR, de Souza LB (2001) Odontogenic tumors: analysis of 127 cases. Pesqui Odontol Bras 15, 308-313.

13. Fernandes AM, Duarte EC, Pimenta FJ, Souza LN, Santos VR, Mesquita RA, de Aguiar MC (2005) Odontogenic tumors: a study of 340 cases in a Brazilian population. J Oral Pathol Med 34, 583587.

14. Avelar RL, Antunes AA, Santos Tde S, Andrade ES, Dourado E (2008) Odontogenic tumors: clinical and pathology study of 238 cases. Braz J Otorhinolaryngol 74, 668-673.

15. Olgac V, Koseoglu BG, Aksakalli N (2006) Odontogenic tumours in Istanbul: 527 cases. Br J
Oral Maxillofac Surg 44, 386-388.

16. Lu Y, Xuan M, Takata T, Wang C, He Z, Zhou Z, Mock D, Nikai H (1998) Odontogenic tumors. A demographic study of 759 cases in a Chinese population. Oral Surg Oral Med Oral Pathol Oral Radiol Endod 86, 707-714.

17. Ochsenius G, Ortega A, Godoy L, Peñafiel C, Escobar E (2002) Odontogenic tumors in Chile: a study of 362 cases. J Oral Pathol Med 31, 415-420.

18. Sriram G, Shetty RP (2008) Odontogenic tumors: a study of 250 cases in an Indian teaching hospital. Oral Surg Oral Med Oral Pathol Oral Radiol Endod 105, e14-21.

19. Adebayo ET, Ajike SO, Adekeye EO (2005) A review of 318 odontogenic tumors in Kaduna, Nigeria. J Oral Maxillofac Surg 63, 811-819.

20. Daley TD, Wysocki GP, Pringle GA (1994) Relative incidence of odontogenic tumors and oral and jaw cysts in a Canadian population. Oral Surg Oral Med Oral Pathol 77, 276-280.

21. Mosqueda-Taylor A, Ledesma-Montes C, CaballeroSandoval S, Portilla-Robertson J, Ruíz-Godoy Rivera LM, Meneses-García A (1997) Odontogenic tumors in Mexico: a collaborative retrospective study of 349 cases. Oral Surg Oral Med Oral Pathol Oral Radiol Endod 84, 672-675.

22. Guerrisi M, Piloni MJ, Keszler A (2007) Odontogenic tumors in children and adolescents. A 15-year retrospective study in Argentina. Med Oral Patol Oral Cir Bucal 12, E180-185.

23. Buchner A, Merrell PW, Carpenter WM (2006) Relative frequency of central odontogenic tumors: a study of 1,088 cases from Northern California and comparison to studies from other parts of the world. J Oral Maxillofac Surg 64, 1343-1352.

24. Tamme T, Soots M, Kulla A, Karu K, Hanstein SM, Sokk A, Jõeste E, Leibur E (2004) Odontogenic tumours, a collaborative retrospective study of 75 cases covering more than 25 years from Estonia. $\mathrm{J}$ Craniomaxillofac Surg 32, 161-165.

25. Jing W, Xuan M, Lin Y, Wu L, Liu L, Zheng X, Tang W, Qiao J, Tian W (2007) Odontogenic tumours: a retrospective study of 1642 cases in a Chinese population. Int J Oral Maxillofac Surg 36, 20-25.

26. Buchner A, Merrell PW, Carpenter WM (2006) Relative frequency of peripheral odontogenic tumors: a study of 45 new cases and comparison with studies from the literature. J Oral Pathol Med 35, 385-391. 